\title{
A systematic review of studies evaluating Australian indigenous community development projects: the extent of community participation, their methodological quality and their outcomes
}

\author{
Mieke Snijder $^{1 *}$, Anthony Shakeshaft ${ }^{1}$, Annemarie Wagemakers $^{2}$, Anne Stephens ${ }^{3}$ and Bianca Calabria ${ }^{4}$
}

\begin{abstract}
Background: Community development is a health promotion approach identified as having great potential to improve Indigenous health, because of its potential for extensive community participation. There has been no systematic examination of the extent of community participation in community development projects and little analysis of their effectiveness. This systematic review aims to identify the extent of community participation in community development projects implemented in Australian Indigenous communities, critically appraise the qualitative and quantitative methods used in their evaluation, and summarise their outcomes.
\end{abstract}

Methods: Ten electronic peer-reviewed databases and two electronic grey literature databases were searched for relevant studies published between 1990 and 2015. The level of community participation and the methodological quality of the qualitative and quantitative components of the studies were assessed against standardised criteria.

Results: Thirty one evaluation studies of community development projects were identified. Community participation varied between different phases of project development, generally high during project implementation, but low during the evaluation phase. For the majority of studies, methodological quality was low and the methods were poorly described. Although positive qualitative or quantitative outcomes were reported in all studies, only two studies reported statistically significant outcomes.

Discussion: Partnerships between researchers, community members and service providers have great potential to improve methodological quality and community participation when research skills and community knowledge are integrated to design, implement and evaluate community development projects.

Conclusion: The methodological quality of studies evaluating Australian Indigenous community development projects is currently too weak to confidently determine the cost-effectiveness of community development projects in improving the health and wellbeing of Indigenous Australians. Higher quality studies evaluating community development projects would strengthen the evidence base.

Keywords: Community development, Indigenous, Aboriginal, Torres Strait Islander, Health promotion, Community participation, Empowerment, Methodological quality, Qualitative, Quantitative

\footnotetext{
* Correspondence: m.snijder@unsw.edu.au

${ }^{1}$ National Drug and Alcohol Research Centre (NDARC), UNSW, Randwick, NSW 2052 Sydney, Australia

Full list of author information is available at the end of the article
} 


\section{Background}

The health gap between Indigenous and non-Indigenous Australians has been well documented [1-3]. Systematic literature reviews, however, have consistently concluded that evaluations of interventions aimed at reducing this health gap lack methodological rigour [4-12]. In addition to improving the methodological quality of the evidence-base, the need for greater community participation in, and control of, Indigenous health promotion research have been advocated [13-15].

Community participation has long been argued as being an essential factor in successful health promotion initiatives [16-18]. A recent meta-analysis concluded that community participation is effective when used in health promotion projects because it engenders greater community motivation and increases the sustainability of projects [19]. Although the review did not include Indigenous communities, the principle of community participation is highly relevant to Indigenous Australians and has great potential to improve Indigenous health. The history of dispossession and disempowerment experienced by Indigenous people highlights the importance of the full and active participation of community members to develop plausible solutions to the problems they themselves have identified $[9,20-25]$. The community development approach strives to empower Indigenous communities to develop and utilise skills that will enable them to more directly address the risk factors that determine their health status [26].

Despite the potential of community development approaches for improving Indigenous health outcomes, there has been no systematic examination of the extent to which they have engendered community participation and little analysis of their effectiveness. The only existing systematic review of Indigenous community development, published in 2007, evaluated 17 projects implemented in Indigenous communities in Australia, Canada, New Zealand and the United States [9]. This review emphasised that high levels of community participation were a critical factor in the success with which community development projects were implemented, however, it did not assess the level of community participation nor systematically assessed the methodological qualities of the studies. This lack of project evaluation has made it difficult to confidently estimate the extent to which community development projects have improved the health and life expectancy of Indigenous People.

This systematic review aims to identify the extent of community participation in community development projects implemented in Australian Indigenous communities, critically appraise the qualitative and quantitative methods used in their evaluation, and summarise their outcomes.

\section{Methods}

Identification of publications

The peer-reviewed and grey literature were searched to identify studies evaluating Indigenous community development projects in Australia, published between 1990 and 2015. Twenty-five years of community development projects was judged to be sufficient to provide an overview of the most recent projects. Figure 1 summarises the databases searched, the search terms used, the eligibility criteria and the classification process based on the PRISMA flow diagram [27].

Ten peer-reviewed databases were searched: Health and Society, Aboriginal and Torres Strait Islander Health Bibliography (ATSIHealth), AIATSIS, APAIS-AIATSIS, FAMILY-ATSIS, ProQuest, Scopus, CINAHL, PsychINFO, and Medline/Pubmed. Two grey literature databases were searched: HealthInfonet and Closing the Gap Clearinghouse. The electronic database search identified 3623 publications and 411 duplicates were removed. Reference lists of the identified publications were scanned which identified an additional 20 publications. Another 11 publications were received from researchers in the field. The resulting 3243 publications were organised in Reference Manager Endnote [28].

\section{Screening and eligibility}

The titles and abstracts of the identified 3243 publications were read to determine their eligibility for inclusion against three criteria: 1 ) relevance to a community development project, including: projects focusing on community ownership, empowerment, local leadership and decision making, adopting a long-term strategy, having a focus on sustainability or having a bottom up approach (i.e. starting from the community) [29, 30]; 2) published between 1990 and 2015; and 3) a primary focus on Indigenous communities in Australia. A total of 231 publications met all three criteria. The full text versions of these 231 publications were sought for detailed review, of which 112 were available and relevant to this review.

\section{Classification}

One hundred and twelve publications were classified into four categories derived from previous research reviewing Indigenous health initiatives [4, 10, 31], defined as follows. Measurement research: the development, testing or evaluation of measurement tools. Evaluation research: an evaluation of an Indigenous community development project or policy. Review: including summaries, critical or systematic reviews and/or meta-analysis; and Discussion paper: general discussion of Indigenous community development. Thirty one publications identified as studies evaluating community development projects in Indigenous Australian communities were critically appraised. 


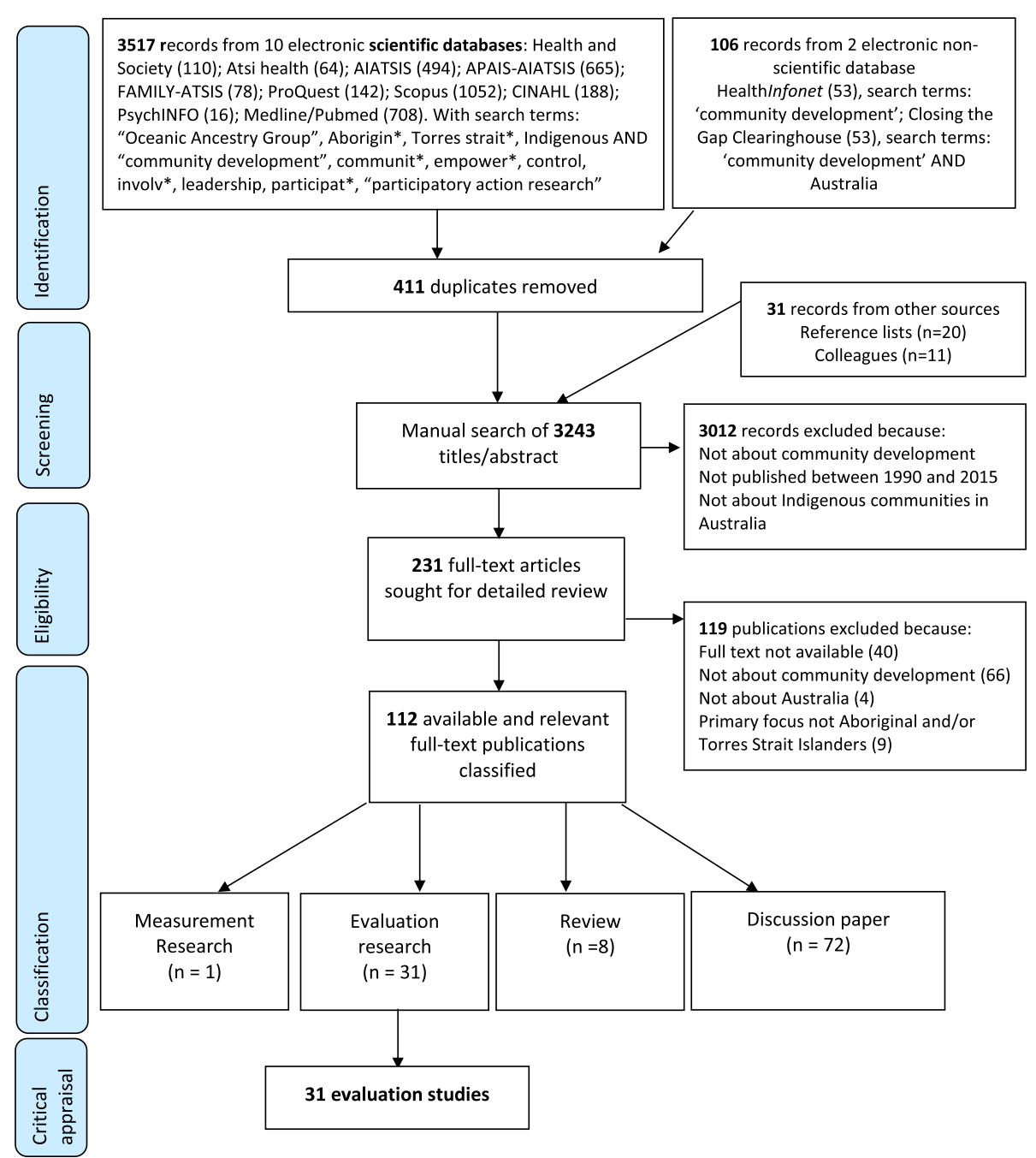

Fig. 1 PRISMA flow diagram: systematic search identifying evaluation studies of Australian Indigenous Community Development projects

\section{Extent of community participation}

Replicating previous analyses [32, 33], the extent of community participation was assessed using Pretty's participation typology, which describes seven levels of community participation ranging from no participation to self-mobilisation (i.e. completely top-down to completely bottom-up) [32, 34]. Given community participation can vary during the lifetime of a project, the extent of participation was assessed separately for four phases of project development: diagnosis (identifying a community's priorities); development (of appropriate strategies to address the priorities); implementation (of the strategies); and evaluation (of the effectiveness of the project) $[32,35,36]$. The level of community participation in the 31 studies were assigned a score between 1 and 7 for each phase of project development. Detailed descriptions of different levels of community participation in relation to scores 1 to 7 , and with respect to all four phases, are provided in Table 1 and are summarised as follows: no participation (score 1); passive participation (score 2 - the community was only informed about the project); participation by information (score 3 - information was collected from the community without their participation and without providing feedback); participation by consultation (score 4 - information was collected from the community, feedback was given and further inclusion of community was sought); functional participation (score 5 - community collaboration, but on outsiders' terms); interactive participation (score 6 - collaboration on mutually defined terms); and self-mobilisation (score 7 - outsider's work in community on community's terms). This scoring was independently conducted by two of the authors (MS and AW), which resulted in agreement for 22 studies (71\%). The nine studies on which authors disagreed were blindly reviewed by a third author (ASt). For four studies, the 
Table 1 Definitions of the seven levels of community participation in the four phases of project development

\begin{tabular}{|c|c|c|c|c|}
\hline \multirow{2}{*}{$\begin{array}{l}\text { Seven levels of community } \\
\text { participation }\end{array}$} & \multicolumn{4}{|c|}{ Four phases of project development } \\
\hline & Diagnosis & Development & Implementation & Evaluation \\
\hline 1. No participation & $\begin{array}{l}\text { Completely top-down, } \\
\text { community is not informed } \\
\text { about or asked about issues } \\
\text { in their community. }\end{array}$ & $\begin{array}{l}\text { Top-down, community is } \\
\text { not informed about the } \\
\text { development of the } \\
\text { project. }\end{array}$ & $\begin{array}{l}\text { Top-down, community } \\
\text { is not informed about } \\
\text { the implementation of } \\
\text { the project, only about } \\
\text { activities they're } \\
\text { involved in }\end{array}$ & $\begin{array}{l}\text { Top-down, community } \\
\text { receives no information } \\
\text { about evaluation. }\end{array}$ \\
\hline 2. Passive participation & $\begin{array}{l}\text { Outsiders decide on the } \\
\text { issues that need to be } \\
\text { addressed, community } \\
\text { is informed. }\end{array}$ & $\begin{array}{l}\text { Outsiders control } \\
\text { development, community } \\
\text { is informed, but has no } \\
\text { input. }\end{array}$ & $\begin{array}{l}\text { Outsiders control the } \\
\text { implementation, } \\
\text { community is informed, } \\
\text { but has no input. }\end{array}$ & $\begin{array}{l}\text { Outsiders control the } \\
\text { evaluation, community } \\
\text { is informed, but has } \\
\text { no input. }\end{array}$ \\
\hline 3. Participation by information & $\begin{array}{l}\text { Outsiders have control, } \\
\text { community participates by } \\
\text { providing information } \\
\text { about their community. } \\
\text { No feedback to the } \\
\text { community and no } \\
\text { checking for agreements. }\end{array}$ & $\begin{array}{l}\text { Outsiders have control } \\
\text { over development, } \\
\text { community potentially } \\
\text { provides information } \\
\text { about what they want, } \\
\text { but outsiders don't } \\
\text { necessarily respond to this. }\end{array}$ & $\begin{array}{l}\text { Outsiders control } \\
\text { implementation, } \\
\text { community might } \\
\text { provide information } \\
\text { useful for implementation, } \\
\text { but outsiders don't } \\
\text { necessarily listed to this. }\end{array}$ & $\begin{array}{l}\text { Outsiders control } \\
\text { evaluation, community } \\
\text { provides information } \\
\text { through surveys and/or } \\
\text { interviews, focus groups. } \\
\text { Findings are not shared } \\
\text { or checked for accuracy. }\end{array}$ \\
\hline 4. Participation by consultation & $\begin{array}{l}\text { Outsiders define problems } \\
\text { and consult with community } \\
\text { about their agreement, } \\
\text { using outsider defined } \\
\text { processes. }\end{array}$ & $\begin{array}{l}\text { Outsiders consult with } \\
\text { community about } \\
\text { potential projects to } \\
\text { develop, but outsiders } \\
\text { make final decision. }\end{array}$ & $\begin{array}{l}\text { Community participates } \\
\text { in activities decided } \\
\text { upon by the outsiders }\end{array}$ & $\begin{array}{l}\text { Outsiders define } \\
\text { evaluation process, } \\
\text { community provides } \\
\text { information and might } \\
\text { make suggestions for } \\
\text { improvement and } \\
\text { feedback provided }\end{array}$ \\
\hline 5. Functional participation & $\begin{array}{l}\text { Outsiders have predetermined } \\
\text { goals and community assists } \\
\text { in defining issues within those } \\
\text { goals, outsiders make final } \\
\text { decisions. }\end{array}$ & $\begin{array}{l}\text { Community works together } \\
\text { with outsiders to develop } \\
\text { projects decided upon by } \\
\text { the outsiders. }\end{array}$ & $\begin{array}{l}\text { Community and } \\
\text { outsiders work towards } \\
\text { implementation of } \\
\text { projects, based on } \\
\text { outsiders' goals and } \\
\text { processes. }\end{array}$ & $\begin{array}{l}\text { Community and } \\
\text { outsiders work together } \\
\text { in evaluation, based on } \\
\text { goals as set by the } \\
\text { outsiders. }\end{array}$ \\
\hline 6. Interactive participation & $\begin{array}{l}\text { Outsiders and community } \\
\text { work together to identify } \\
\text { the issues in the community } \\
\text { and set goals for the project. }\end{array}$ & $\begin{array}{l}\text { Outsiders and community } \\
\text { work together to develop } \\
\text { suitable projects to address } \\
\text { the agreed upon goals. }\end{array}$ & $\begin{array}{l}\text { Community and outsiders } \\
\text { implement the developed } \\
\text { projects together, } \\
\text { community has control } \\
\text { and uses local resources. }\end{array}$ & $\begin{array}{l}\text { Evaluation methods are } \\
\text { decided upon together } \\
\text { and conducted in } \\
\text { partnership. }\end{array}$ \\
\hline 7. Self-mobilisation & $\begin{array}{l}\text { Completely bottom-up, } \\
\text { community identifies their } \\
\text { own issues and sets their } \\
\text { own goals, might contact } \\
\text { outsiders to assist them } \\
\text { where needed. }\end{array}$ & $\begin{array}{l}\text { Bottom-up, community } \\
\text { makes decisions about } \\
\text { project development, } \\
\text { apply for funding and } \\
\text { potentially contact } \\
\text { outsiders where needed }\end{array}$ & $\begin{array}{l}\text { Community implements } \\
\text { projects, contacts } \\
\text { outsiders for resources } \\
\text { where needed, but } \\
\text { remains in control over } \\
\text { resources. }\end{array}$ & $\begin{array}{l}\text { Community conducts } \\
\text { evaluations, potentially } \\
\text { contacts outsiders for } \\
\text { assistance, but stays in } \\
\text { control over evaluation. }\end{array}$ \\
\hline
\end{tabular}

Source: adapted from Pretty (1995) and Wagemakers et al. (2008)

score allocated by the third reviewer was the same as the score allocated by one of the first two reviewers and so that score was used, increasing the agreement rate to $84 \%$ for 26 of the 31 studies. For the five studies where there was no agreement, the scores allocated by the first author (MS) were used.

\section{Critical appraisal of methodology Qualitative methods}

The methodological quality of the qualitative study components was assessed by adapting Long and Godfrey's qualitative study evaluation tool, which was developed to appraise evaluations of health and social care interventions [37]. This tool has 4 sections: 1) phenomenon studied and context; 2) ethics; 3) data collection, analysis and potential research bias; and 4) policy and practical implications. The latter two were used in this review because they relate specifically to evaluation issues. Data collection includes the need for clear descriptions of the data collection process (e.g. recruitment strategies, data collection procedures, specifying the interview questions, methods of recording data and the extent to which the data collection process was tailored to specific communities). Data analysis includes the description of the data analysis, the provision of adequate evidence to support the analysis (including data extracts, triangulations and descriptions of reliability) and whether the findings are interpreted in line with existing theories and literature. 
Potential researchers' bias assesses whether the position of the researcher is outlined in the study and its potential influence on the data collection and analysis. The policy and practical implications include an analysis of the populations and settings to which the findings are generalisable, the implications for policy or practice, and the extent to which the methods justify the conclusions.

\section{Quantitative methods}

The methodological quality of the quantitative study components was appraised using the Dictionary for Effective Public Health Practice Project Quality Assessment tool for Quantitative studies [38], which was developed to review public health studies and has been used in other systematic reviews in the Australian Indigenous health field $[4,10]$. Sections A-F (A - selection bias, B - study design, C - confounders, D - blinding, E - data collection methods, F - withdrawals and drop-out) are rated categorically as strong, moderate or weak. Sections G (intervention integrity) and $\mathrm{H}$ (analysis appropriateness) comprise summaries of the relevant information rather than categorical ratings. In addition to sections $\mathrm{A}-\mathrm{H}$, this tool advocates a summary rating defined as weak (two or more weak scores are given), moderate ( 1 weak score is given) or strong (no weak scores are given).

\section{Scoring for critical appraisal of methodology}

Scores against both the qualitative and quantitative evaluation criteria were allocated by author MS. A random selection of $25 \%$ of studies were assessed by a blinded coder (ASt). There was agreement for $70 \%$ of these studies. Disagreements were resolved in consultation between the two coders.

\section{Outcomes of the studies}

The outcomes of the studies evaluating Indigenous community development projects are summarised.

\section{Results}

Thirty-one studies evaluating Indigenous community development projects in Australia were identified. Ten (32\%) were published in the peer reviewed literature [39-48].

\section{Extent of community participation}

Table 2 summarises the level of community participation across the four phases of project development for each study. Table 3 summarises the number of studies relevant to each of the seven levels of community participation, separately for the four phases of project development. The highest levels of participation (level 5 to level 7), were found in the Diagnosis phase for ten studies (32\%) [39, 43, 44, 48-54], in the Development phase for 13 studies (42\%) [39-44, 46, 49-52, 54, 55], in the Implementation phase for 17 studies (55\%) [39-44, 46, 48-54, 56-58] and in the Evaluation phase for 7 studies (22\%) [39, 40, 43, 44, 50, 53, 59]. Four studies (13\%) had at least level 5 participation in all phases of the project $[39,43,44,50]$. The participation of the community was described with insufficient detail to be assessed (unknown category) for ten studies in the Diagnosis phase (32\%) [42, 45, 57, 58, 60-65], seven in the Development phase (23\%) [47, 48, 57, 60, 61, 64, 66], four (12.9 \%) in the Implementation phase $[47,61,63,66]$ and two $(7 \%)$ in the Evaluation phase $[46,67]$.

\section{Methods used in studies}

Twenty-one studies $(67 \%)$ used qualitative methods only [39-41, 48, 49,51,52, 55-57, 59-69], two (7\%) used quantitative methods only [46, 47], and eight (26\%) used mixed methods [42-45, 53, 54, 58, 59]. Qualitative data were collected using semi-structured interviews in 24 studies [ $39,40,42,43,45,49-53,55-58$, 60-69], document analysis $(n=15[42,49,51,52,55-57$, 60-66, 68]), focus groups $(n=9[39,40,43,45,48-50$, $53,58])$, participant observation $(n=6[42,43,53,54$, $58,69])$ and photovoice [70] $(n=2[50,53])$. Quantitative data collection methods included surveys in three studies [45, 48, 58], hospital/clinical records $(n=4$ $[43,44,47,53])$, school records $(n=2[42,58])$, police records $(n=1$ [42]), store records $(n=1$ [43]) and ABS census data $(n=1[46])$.

\section{Methodological quality of studies with a qualitative component}

All 29 studies with a qualitative component (including mixed methods studies) provided some description of the evaluation methods used (Table 4). Twelve studies (41 \%) gave detailed descriptions of the data collection process, including participant recruitment, focus group procedures and a clear description of which data were recorded [39, 41, 49-51, 53, 58, 60-63, 67]. Four of these twelve studies $(14 \%)$ provided the interview questions [51, 58, 60,67] and one study (4\%) described in detail how the data collection methods were tailored to ensure their cultural appropriateness [49]. The data analysis methods were described in detail in seven studies (24\%) [39, 42, 50, 54, 58, 67, 69]. The potential for researcher bias was described in seven studies (24\%) $[39,44,45,49,53,58,69]$. Three studies (10 \%) did not discuss the implications of their findings [52, 59, 65].

\section{Methodological quality of studies with a quantitative component}

The summary ratings for all ten studies with a quantitative component were classified as weak (Table 5). The 
Table 2 Level of community participation in each phase of project development for each study

\begin{tabular}{|c|c|c|c|c|}
\hline \multirow[t]{2}{*}{ First author (year) } & \multicolumn{4}{|c|}{ Four phases of project development } \\
\hline & Diagnosis & Development & Implementation & Evaluation \\
\hline Gauld et al. (2011) [40] & $1^{\mathrm{a}}$ & $2-5^{b}$ & $2-5$ & 5 \\
\hline Green et al. (2009) [67] & 4 & 4 & 4 & UNK \\
\hline McMurray (2012) [49] & 7 & 6 & 6 & 3 \\
\hline Parker et al. (2006) [48] & 6 & UNK & 5 & 4 \\
\hline Murphy et al. (2004) [41] & 3 & 7 & 5 & 4 \\
\hline Hunt (2010a) [59] & 7 & 7 & 7 & 6 \\
\hline CLC (2012a) [60] & UNK & UNK & 4 & 3 \\
\hline CLC (2012b) [51] & 7 & 7 & 7 & $3 / 4^{c}$ \\
\hline CLC (2012C) [61] & UNK & UNK & UNK & $3 / 4$ \\
\hline CLC (2012d) [62] & UNK & 3 & 3 & 4 \\
\hline CLC (2012e) [63] & UNK & 4 & UNK & 3 \\
\hline Taylor (2005a) [56] & 1 & UNK & 5 & 4 \\
\hline Taylor (2005b) [64] & UNK & UNK & 4 & 4 \\
\hline Ramsay (2005a) [57] & UNK & UNK & 5 & 4 \\
\hline Ramsay (2005b) [68] & 1 & 3 & 4 & 4 \\
\hline Burchill (2005) [65] & UNK & 3 & 4 & 4 \\
\hline Higgins (2005) [52] & 7 & 7 & 7 & 4 \\
\hline Bromfield (2005) [55] & 1 & 5 & 4 & 4 \\
\hline Ramsay (2005c) [66] & 2 & UNK & UNK & 4 \\
\hline Tsey (2003) [69] & 1 & 3 & 4 & 3 \\
\hline Tsey et al. (2004); [39] & 5 & 6 & 6 & 5 \\
\hline Smith (2004) [53] & 7 & 3 & 6 & 6 \\
\hline Lee et al. (2008) [42] & UNK & $2-5$ & $4-5$ & 4 \\
\hline Tyrrell et al. (2003) [43] & 6 & 6 & 6 & 5 \\
\hline Guenther (2011) [58] & UNK & 2 & 5 & 2 \\
\hline Salisbury (1998) [44] & 5 & $5 / 6$ & $5 / 6$ & 6 \\
\hline Hunt (2010b) [59] & 1 & 2 & 4 & 5 \\
\hline Moran (2003/2004) [45] & UNK & 4 & $4-1$ & 2 \\
\hline McCalman (2005) [54] & 7 & 7 & 7 & 4 \\
\hline Jarvie (2008) [46] & 1 & 5 & 5 & UNK \\
\hline Shannon et al. (2001) [47] & 3 & UNK & UNK & 3 \\
\hline
\end{tabular}

apossible scores range from 1 to $7: 1$ = no participation; 2 = passive participation; 3 = participation by information; $4=$ participation by consultation; 5 = functional participation; $6=$ interactive participation; $7=$ self-mobilisation, UNK = unknown $[32,34]$

${ }^{\mathrm{b}}$ Participation varied within the phase

${ }^{\mathrm{C}}$ Participation was somewhere in between these levels

likely extent of selection bias was unclear for six studies (60\%) because description of the participant and community selection procedures was absent or insufficiently detailed [42-44, 46, 47, 59]. Five studies (50 \%) used a cohort design without a control group [43-45, 53, 54], one study (10\%) used a time series design [47] and the evaluation design of the remaining four studies (40\%) was unclear [42, 46, 58, 59]. No study adequately controlled for confounding variables. None of the studies used blinding procedures. Two studies (20\%) used validated outcome measures $[45,58]$. No study discussed the validity or reliability of their outcome measures.

One study (10\%) described withdrawals and drop outs at the community level [46]. One study (10\%) described withdrawals and drop outs at the participant level [53]. Drop outs at the participant level were not applicable for the six studies $(60 \%)$ that used either routinely collected data or a one-off survey [42-44, 47, 54, 58]. Two studies (20 \%) did not report drop outs $[45,59]$. No study described the fidelity of the project. Three studies (30\%) 
Table 3 Number of studies across the levels of community participation and phases of project development

\begin{tabular}{|c|c|c|c|c|}
\hline \multirow[t]{2}{*}{ Seven levels of community participation } & \multicolumn{4}{|c|}{ Four phases of project development } \\
\hline & Diagnosis & Development & Implementation & Evaluation \\
\hline 1. No participation & 7 & & & \\
\hline 2. Passive participation & 1 & 3 & & 2 \\
\hline 3. Participation by information & 2 & 3 & & 6 \\
\hline 4. Participation by consultation & 1 & 5 & 10 & 14 \\
\hline Least active involvement sub-total (levels 1-4) & 11 & 11 & 10 & 22 \\
\hline 5. Functional participation & 1 & 4 & 8 & 4 \\
\hline 6. Interactive participation & 3 & 4 & 5 & 3 \\
\hline 7. Self-mobilisation & 6 & 5 & 4 & 0 \\
\hline Most active involvement sub-total (levels 5-7) & 10 & 13 & 17 & 7 \\
\hline Unknown & 10 & 7 & 4 & 2 \\
\hline Total & 31 & 31 & 31 & 31 \\
\hline
\end{tabular}

Note: No participation = community did not participate

Passive participation $=$ the community was only informed about the project

Participation by information = information was collected from the community without their participation and without providing feedback. Participation by consultation = information was collected from the community, feedback was given and further inclusion of community was sought

Functional participation $=$ community collaboration on outsider's terms

Interactive participation = collaboration on mutually defined terms

Self-mobilisation $=$ outsider's work in community on community's terms $[32,34]$

reported on the exposure of participants to the project $[45,54,58]$. Inferential statistical analyses were reported by four studies (40\%) [42, 47, 53, 58].

\section{Outcomes}

A summary of the aims and key outcomes for each study is provided in Table 6. All studies using qualitative methods concluded that community members reported positive project impacts for their community. Two studies (7 \%) reported quantitative outcomes that were statistically significant: a reduction in injuries [47] and a reduction in cannabis use among females aged 13-36 and males aged over 16 years [42].

\section{Discussion}

This study systematically reviewed the peer-reviewed and grey literature on community development projects in Australian Indigenous communities. One hundred and twelve relevant and available publications were identified, 31(28 \%) studies were evaluations, 21of these evaluation studies $(68 \%)$ were published in grey literature. There were no marked differences observed between evaluations published in the grey and peerreviewed literature in terms of the detailed descriptions of the qualitative methods used, the quality of the quantitative methods or the reported levels of community participation. This high comparability reflects the generally low quality of all the evaluations published in both the peer-review and the grey literature. It would be an asset to the community development field to increase the publication rate of higher-quality evaluation studies in the peer reviewed literature, especially in open access journals, to utilise peer review as a quality assurance mechanism and to optimise the transparency of study results.

\section{Community participation in community development projects}

Community participation was assessed as moderate in most of the studies evaluating Indigenous community development projects $(87 \%)$. The wide variation in community participation between projects and project phases, and within project phases, in these Australian Indigenous studies is reflected in the international literature $[32,36]$. For half of the studies included in this review, the intent for community participation was clearly described, but the actual level of participation was not reported for at least one of the phases of project development. Documenting the community participation strategies and processes used, including details about how the community was engaged and who in the community participated, would allow the more successful community participation strategies to be identified and replicated in subsequent projects [36].

Although the unique characteristics of each community will lead to variation in their capacity to participate in each phase of a project $[36,71]$, the extent and nature of community participation can be optimised by careful planning and the utilisation of appropriate frameworks to guide the development, implementation and evaluation of community-based projects. An approach like participatory action research provides practical guidelines to achieve this [72, 73]. 
Table 4 Critical appraisal of qualitative components of studies evaluating Indigenous community development projects $(n=29)$

\begin{tabular}{|c|c|c|c|c|}
\hline First author (year) & Data collection & Data analysis & Potential bias & Implications \\
\hline \multicolumn{5}{|c|}{ Qualitative only studies $(n=21)$} \\
\hline Gauld et al. (2011) [40] & Little detail & Not described & Not described & $\begin{array}{l}\text { Generalised to far northern } \\
\text { Queensland communities }\end{array}$ \\
\hline Green et al. (2009) [67] & $\begin{array}{l}\text { Detailed description, } \\
\text { including interview } \\
\text { questions }\end{array}$ & $\begin{array}{l}\text { Detailed description } \\
\text { and linked to literature }\end{array}$ & Not described & $\begin{array}{l}\text { Generalised to organisations } \\
\text { working with Indigenous } \\
\text { communities in Australia } \\
\text { and policy }\end{array}$ \\
\hline McMurray (2012) [49] & $\begin{array}{l}\text { Detailed description } \\
\text { of field work }\end{array}$ & Not described & $\begin{array}{l}\text { Position of researcher } \\
\text { described }\end{array}$ & $\begin{array}{l}\text { Implications for the funding } \\
\text { agency }\end{array}$ \\
\hline Parker et al. (2006) [48] & Not described & Not described & Not described & $\begin{array}{l}\text { Described for health } \\
\text { promotion work in } \\
\text { Indigenous communities }\end{array}$ \\
\hline Murphy et al. (2004) [41] & Detailed description & Not described & Not described & $\begin{array}{l}\text { Appreciative inquiry methods } \\
\text { and culture projects }\end{array}$ \\
\hline CLC (2012a) [60] & Detailed description & $\begin{array}{l}\text { Description of who } \\
\text { did analysis and } \\
\text { triangulation }\end{array}$ & Not described & Described for organisation \\
\hline CLC (2012b) [51] & Detailed description & $\begin{array}{l}\text { Description of who } \\
\text { did analysis and } \\
\text { triangulation }\end{array}$ & Not described & Described for organisation \\
\hline CLC (2012C) [61] & Detailed description & $\begin{array}{l}\text { Description of who } \\
\text { did analysis and } \\
\text { triangulation }\end{array}$ & Not described & Described for organisation \\
\hline CLC (2012d) [62] & Detailed description & $\begin{array}{l}\text { Description of who } \\
\text { did analysis and } \\
\text { triangulation }\end{array}$ & Not described & Described for organisation \\
\hline CLC (2012e) [63] & Detailed description & $\begin{array}{l}\text { Description of who } \\
\text { did analysis and } \\
\text { triangulation }\end{array}$ & Not described & Described for organisation \\
\hline Taylor (2005a) [56] & Little detail & Not described & Not described & $\begin{array}{l}\text { Generalised to comparable } \\
\text { projects }\end{array}$ \\
\hline Taylor (2005b) [64] & $\begin{array}{l}\text { Little detail, mention } \\
\text { of development of } \\
\text { evaluation tool }\end{array}$ & Not described & Not described & $\begin{array}{l}\text { Described for future } \\
\text { communities wanting to } \\
\text { implement project }\end{array}$ \\
\hline Ramsay (2005a) [57] & Little detail & Not described & Not described & $\begin{array}{l}\text { Generalised to Indigenous } \\
\text { communities with } \\
\text { comparable issues }\end{array}$ \\
\hline Ramsay (2005b) [68] & Little detail & Not described & Not described & $\begin{array}{l}\text { Discussed for working with } \\
\text { Indigenous communities }\end{array}$ \\
\hline Burchill (2005) [65] & Very little detail & Not described & Not described & Not described \\
\hline Higgins (2005) [52] & Very little detail & Not described & Not described & Not described \\
\hline Bromfield (2005) [55] & Very little detail & Not described & Not described & Discussed for practice \\
\hline Ramsay (2005c) [66] & Very little detail & Not described & Not described & Discussed for practice \\
\hline Tsey (2003) [69] & Detailed description & Detailed description & $\begin{array}{l}\text { Position of researcher } \\
\text { is discussed }\end{array}$ & $\begin{array}{l}\text { Generalised to community } \\
\text { development projects and } \\
\text { practice }\end{array}$ \\
\hline Tsey et al. (2004); [39] & Very detailed description & Detailed description & $\begin{array}{l}\text { Position of researcher } \\
\text { discussed }\end{array}$ & $\begin{array}{l}\text { Discussed for practice, } \\
\text { policy and researcher }\end{array}$ \\
\hline Hunt (2010b) [59] & Not described & Not described & Not described & Not described \\
\hline \multicolumn{5}{|l|}{ Mixed Methods Studies $(n=8)$} \\
\hline Hunt (2010a) [59] & $\begin{array}{l}\text { Detailed description } \\
\text { of fieldwork }\end{array}$ & Described & $\begin{array}{l}\text { Researcher position } \\
\text { and bias described }\end{array}$ & $\begin{array}{l}\text { Described for organisation's } \\
\text { community development work }\end{array}$ \\
\hline Smith (2004) [53] & Very detailed description & $\begin{array}{l}\text { Description of who } \\
\text { analysed data, but } \\
\text { not methods }\end{array}$ & $\begin{array}{l}\text { Position of researcher } \\
\text { discussed }\end{array}$ & $\begin{array}{l}\text { Generalised to other communities, } \\
\text { implications for project described }\end{array}$ \\
\hline
\end{tabular}


Table 4 Critical appraisal of qualitative components of studies evaluating Indigenous community development projects $(n=29)$ (Continued)

\begin{tabular}{|c|c|c|c|c|}
\hline Lee et al. (2008) [42] & Detailed description & Described & Not described & $\begin{array}{l}\text { Generalised to communities } \\
\text { with similar problems. }\end{array}$ \\
\hline Tyrrell et al. (2003) [43] & Not described & Not described & Not described & $\begin{array}{l}\text { Discussed for practice and } \\
\text { results }\end{array}$ \\
\hline Guenther (2011) [58] & Detailed description & Detailed description & $\begin{array}{l}\text { Position of researcher } \\
\text { discussed }\end{array}$ & $\begin{array}{l}\text { Discussed for policy and } \\
\text { practice }\end{array}$ \\
\hline Salisbury (1998) [44] & Little detail & Not described & $\begin{array}{l}\text { Researcher position } \\
\text { discussed }\end{array}$ & $\begin{array}{l}\text { Generalised to health services } \\
\text { in Indigenous communities }\end{array}$ \\
\hline Moran (2003/2004) [45] & Detailed description & $\begin{array}{l}\text { Description of who } \\
\text { analysed data, but } \\
\text { not methods }\end{array}$ & $\begin{array}{l}\text { Researcher position } \\
\text { and bias discussed }\end{array}$ & Discussed for practice \\
\hline McCalman (2005) [54] & Very little detail & Very little detail & Not described & Discussed for practice \\
\hline
\end{tabular}

\section{Quality of evaluation methodology}

In line with previous research [4-12], the methodological quality of the studies identified in this review are poor, or they are difficult to assess because their methods are inadequately described. It is acknowledged that issues specific to Indigenous community-based research can impact on the research quality, including time needed to engage with the community, difficulties with recruiting enough participants, high staff turn-over at service providers and culturally-specific delays (e.g. ceremonies or celebrations) [14]. Careful and flexible planning is therefore needed in community development projects to address these issues to reduce their impact on the quality of the research. The complex interventions framework, for example, provides one mechanism to carefully plan projects to maintain methodological rigour $[74,75]$. The methodological quality of qualitative studies could also be improved by using appropriate analysis methods, multiple coders, and describing the extent of potential bias attributable to the researcher [37].

The methodological rigour of both the qualitative and the quantitative studies could further be improved by using measures with demonstrated reliability and validity: only two studies identified by this review reported that they had used such measures $[45,58]$. Using reliable and valid measures increases confidence in the accuracy of the study outcomes [76]. Such measures should be validated specifically for the Indigenous population, because of their holistic concept of health and wellbeing [77]. Existing studies show that it is possible to develop reliable and valid measures that are culturally appropriate and acceptable to Indigenous Australians [78-83], but the lack of measurement studies specifically related to community projects identified in this review (one study, see Fig. 1) clearly indicates that more of this measurement research is urgently needed [80].

Only three studies $(10 \%)$ reported on intervention integrity, which includes the level of exposure to the project, and the consistency and frequency with which project components were delivered in practice. Studies evaluating community development projects would be improved by routinely including process measures, to allow an examination of the extent to which outcomes are a consequence of the project components, as opposed to reflecting the extent to which the project components were implemented [74].

Eight studies $(26 \%)$ evaluated a community development project using a mixed methods design. Increasing the use of mixed methods is likely to optimally improve the effectiveness of future community-based evaluations because they provide a greater range of relevant data $[11,84]$ : quantitative analysis can provide rigorous methods to evaluate the effectiveness and costs of projects, while qualitative data can capture community members' experiences [85] and help identify the project elements that are most acceptable to community members [11].

The critical appraisal also identified a lack of detailed reporting of the methodologies used, especially in relation to the qualitative evaluations. Only $41 \%$ of the qualitative studies reported on their data collection process, for example, and only $24 \%$ reported the data analysis methods that were used. Future Indigenous community development evaluations would benefit from more detailed reporting using established guidelines, such as the COREQ criteria for qualitative research [86] or the guidelines recommended by the Equator Network [87]. In addition to improving reporting standards, using these guidelines in the development, implementation and evaluation phases of community development projects would most likely improve the quality of the interventions and their evaluation [37, 38].

Outcomes of indigenous community development projects There is currently insufficient evidence about the impact of community development projects on health and wellbeing outcomes for Indigenous Australians. Although all 
Table 5 Critical appraisal of quantitative component of studies evaluating Indigenous community development projects $(n=10)$

\begin{tabular}{|c|c|c|c|c|c|c|c|c|c|}
\hline 1st author, year & $\begin{array}{l}\text { Selection } \\
\text { bias (A) }\end{array}$ & Study design (B) & Confounds (C) & Blinding (D) & $\begin{array}{l}\text { Data collection } \\
\text { methods (E) }\end{array}$ & $\begin{array}{l}\text { Withdrawal \& } \\
\text { drop-outs (F) }\end{array}$ & Intervention integrity (G) & Analysis $(H)$ & $\begin{array}{l}\text { Summary } \\
\text { rating }\end{array}$ \\
\hline \multicolumn{10}{|c|}{ Mixed method studies $(n=8)$} \\
\hline Smith (2004) [53] & Moderate & Moderate & NA & Weak & Weak & Moderate & $\begin{array}{l}\text { Collection of quantitative data } \\
\text { stopped before real community } \\
\text { action started. }\end{array}$ & $\begin{array}{l}\text { Community-level allocation, } \\
\text { individual-level analysis. No } \\
\text { appropriate analysis of change } \\
\text { in child growth over time. }\end{array}$ & Weak \\
\hline Lee (2008) $[42]^{a}$ & Weak & Weak & NA & Moderate & Weak & Moderate & $\begin{array}{l}\text { Many youth involved in the } \\
\text { interventions, no information } \\
\text { on consistency, other community } \\
\text { initiatives were running } \\
\text { simultaneously (including stricter } \\
\text { supply controls and rewards } \\
\text { linked to school attendance). }\end{array}$ & $\begin{array}{l}\text { Community-level allocation and } \\
\text { analysis. Statistical methods } \\
\text { described in other publication. } \\
\text { Dates of data collection } \\
\text { (2001-2004) do not line up } \\
\text { with dates of intervention } \\
\text { (2003-2005), no post-test data. }\end{array}$ & Weak \\
\hline Tyrell (2003) [43] ${ }^{\mathrm{a}}$ & Weak & Weak & NA & Moderate & Weak & Moderate & $\begin{array}{l}\text { No description of who was } \\
\text { exposed to the project and who } \\
\text { weren't, nor of possible external } \\
\text { influences on outcomes. }\end{array}$ & $\begin{array}{l}\text { Allocation on community and } \\
\text { individual level. Evaluation on } \\
\text { community, organisational and } \\
\text { individual level. No statistical } \\
\text { analysis (outcomes as } \\
\text { percentages only). }\end{array}$ & Weak \\
\hline Guenther (2011) [58] & Strong & Weak & NA & Weak & Weak & N/A & $\begin{array}{l}\text { All participants were part of the } \\
\text { project; not all participants } \\
\text { attended every session; it is likely } \\
\text { that the results were influenced } \\
\text { by other interventions put on } \\
\text { the families. }\end{array}$ & $\begin{array}{l}\text { Individual-level allocation and } \\
\text { analysis; statistical analyses } \\
\text { (frequencies and } t \text {-test) were } \\
\text { appropriate; analysis performed } \\
\text { on actual intervention status. }\end{array}$ & Weak \\
\hline Salisbury (1998) [44] ${ }^{a}$ & Weak & Moderate & NA & Weak & Weak & Moderate & $\begin{array}{l}\text { No description of exposure or } \\
\text { consistency; no mention of other } \\
\text { interventions influencing } \\
\text { outcomes; tested for population } \\
\text { growth (which didn't grow) }\end{array}$ & $\begin{array}{l}\text { Unit of allocation and analysis } \\
\text { are on organizational level. } \\
\text { No statistical analysis. }\end{array}$ & Weak \\
\hline Hunt (2010b) [59] & Weak & Weak & Weak & Weak & Weak & Weak & $\begin{array}{l}\text { No description of exposure or } \\
\text { consistency, potential influence } \\
\text { of other interventions running in } \\
\text { the communities at the same time. }\end{array}$ & $\begin{array}{l}\text { Unit of allocation community } \\
\text { and organisational level, unit } \\
\text { of analysis individual level, } \\
\text { no statistical analysis. }\end{array}$ & Weak \\
\hline Moran (2003) $[45]^{\mathrm{a}}$ & Moderate & Moderate & NA & Weak & Moderate & Weak & $\begin{array}{l}92 \% \text { of participants reported } \\
\text { awareness of town plan. } \\
\text { Outcomes may be influenced } \\
\text { by the cycle of optimism and } \\
\text { pessimism. }\end{array}$ & $\begin{array}{l}\text { Unit of allocation is community } \\
\text { level, analysis is done on } \\
\text { community and individual level. } \\
\text { No statistical analysis. }\end{array}$ & Weak \\
\hline
\end{tabular}


Table 5 Critical appraisal of quantitative component of studies evaluating Indigenous community development projects $(n=10)$ (Continued)

\begin{tabular}{|c|c|c|c|c|c|c|c|c|c|}
\hline McCalman (2005) [54] & Moderate & Moderate & NA & NA & Weak & Weak & $\begin{array}{l}\text { All evaluation participants were } \\
\text { exposed to intervention; } \\
\text { consistency was not measured; } \\
\text { outcomes likely influenced by } \\
\text { other factors. }\end{array}$ & $\begin{array}{l}\text { Project was allocated at } \\
\text { organizational level, data were } \\
\text { collected on community level, } \\
\text { cannot be sure whether } \\
\text { changes at community level } \\
\text { are caused by changes at } \\
\text { the organizational level. No } \\
\text { statistical analysis }\end{array}$ & Weak \\
\hline \multicolumn{10}{|c|}{ Quantitative only studies $(n=2)$} \\
\hline Jarvie (2008) $[46]^{a}$ & Weak & Weak & Weak & Weak & Weak & Strong & $\begin{array}{l}\text { One community withdraw } \\
\text { temporarily, others stayed. } \\
\text { There's a chance that outcomes } \\
\text { are influenced by other } \\
\text { developments going on at the } \\
\text { same time }\end{array}$ & $\begin{array}{l}\text { No statistical analysis, intervention } \\
\text { offered at community level, data } \\
\text { gathered at population level. }\end{array}$ & Weak \\
\hline Shannon (2001) [47] ${ }^{a}$ & Weak & Moderate & N/A & Weak & Weak & Moderate & $\begin{array}{l}\text { No description of exposure to } \\
\text { intervention or consistency in } \\
\text { delivery. Outcomes may be } \\
\text { influenced by other factors }\end{array}$ & $\begin{array}{l}\text { Community-level allocation and } \\
\text { analysis. Appropriate statistical } \\
\text { analysis. }\end{array}$ & Weak \\
\hline
\end{tabular}

Note: Appraised using the Dictionary for Effective Public Health Practice Project Quality Assessment tool [38]

${ }^{\text {a }}$ Published in peer-reviewed literature 
Table 6 Aims and outcomes of studies evaluating Indigenous community development project $(n=31)$

\begin{tabular}{ll}
\hline First author (year) & Project aim \\
\hline Gauld et al. (2011) [40] & Developing culturally relevant rehabilitation \\
& service for adults with acquired brain injury.
\end{tabular}

Green et al. (2009) [67]

McMurray (2012) [49]

Parker et al. (2006) [48]

Murphy et al. (2004) [41]

Hunt (2010a) [59]

CLC (2012a) [60]

CLC (2012b) [51]

CLC (2012C) [61]

CLC (2012d) [62]

CLC (2012e) [63]

Taylor (2005a) [56]

Taylor (2005b) [64]

Ramsay (2005a) [57]

Ramsay (2005b) [68]

Burchill (2005) [65]

Higgins (2005) [52]
Community empowerment through arts and cultural practice

Increase self-determination of women of the community

Introduce Indigenous games in schools to increase physical activity

Enable indigenous people to identify positively with their culture

Encourage healing and harmony for and between (non) Aboriginal people. (Partnership Oxfam and Yorgum)

Increase community understanding and control of usage of mine royalties to facilitate community development

Use aboriginal royalties to support education and training initiatives

Improve quality of dialysis service

Develop community initiatives and plans for commercial enterprises

Establishing community development to achieve benefits from income from national parks

Build capacity of Indigenous Health Worker(IHW) to address childhood asthma and educate community about asthma.

Revitalizing cultural knowledge through traditional games to improve health and build capacity.

Increase awareness of nutritional need of children and improve early childhood health.

Developing and publishing literacy resources to improve literacy

Revitalizing cultural knowledge through multimedia databases and developing computer skills.

Empower Indigenous youth and strengthen links with their culture
Outcomes of study

Experienced increase in knowledge about and access to services for people with acquired brain injuries.

Social issues addressed; Non-indigenous staff reported improved understanding Indigenous issues; community members acquiring new skills; experienced increase in supportive relationships and friendships

Increased networking; improved community governance; increased livelihood opportunities.

Process evaluation: most people were satisfied with forum, workshops and activities; project is transferred to other communities.

Youth experienced acquiring wide range of skills; development of pride and connectedness to community and culture; improved self-esteem.

Family issues were addressed; improved parenting skills; less stress; behavioural change; empowerment.

Increased community understanding and perceived and actual community control; increase perceived benefits of project and increase in projects that support the whole community.

Perceived improvements in school performance and increase youth employment; growing capacity and ability of committee. Observed increase in school attendance because of school excursions.

Service now strongly contributes to health and wellbeing of family, patients and community

Good relationships are built with stakeholders; increased perceived community control; creating activities for community.

Commitment to projects that increase community benefits; planning of projects emerged.

Increased skill transfer and development of $\mathrm{HWW}$; increased confidence in administering own asthma medication; improved relationships doctors and $I \mathrm{HWS}$

Youth experienced increased confidence. Revitalized cultural pride. Indigenous and non-Indigenous people drawn together; empowering.

Observed increased awareness nutritional needs, decrease failure to thrive kids and increase in fruits and vegetables in store. Increase confidence in buying healthy food; increase of healthier kids in community. Establishment of community garden.

Publishing and increased use of picture dictionary as effective tool to teach English as a second language.

Observed improvement of computer and literacy skills; increase in self-pride and pleasure; generations are drawn together.

Experienced increase in job offers, improved wellbeing of youth. Reported increase in youth entering higher education; decreased expulsions. 
Table 6 Aims and outcomes of studies evaluating Indigenous community development project $(n=31)$ (Continued)

\begin{tabular}{ll}
\hline Bromfield (2005) [55] & $\begin{array}{l}\text { Develop confidence, self-esteem and } \\
\text { in Indigenous history, }\end{array}$ \\
Ramsay (2005c) [66] & Identify and assist emerging youth \\
& community leaders
\end{tabular}

Tsey (2003) [69]

Tsey et al. (2004); [39]

Smith (2004) [53]

Lee et al. (2008) [42]

Tyrrell et al. (2003) [43]

Guenther (2011) [58]

Salisbury (1998) [44]

Hunt (2010b) [59]

Moran (2003/2004) [45]

McCalman (2005) [54]

Jarvie (2008) [46]

Shannon et al. (2001) [47]
Improve physical, mental, emotional and spiritual wellbeing of individuals and families.

Restore men's rightful place in the community

Improving child growth and increasing community involvement.

Address youth substance misuse and crime and develop youth activities

Improve knowledge about and management of diabetes

Strengthen and empower families to help children succeed in life

Improve development and delivery of Aboriginal and Torres Strait Island Mental Health service

Build financial capacity in Aboriginal communities

Establishing healthy and sustainable living environment

Restore men's rightful place in the community

Improve relationship between communities and government and build community capacity.

Reduce injuries in the community
Emerging of real career pathways; observed change in children's confidence and behaviour.

Youth getting more active in community; youth staying in school longer; observed increase in youth taking employment opportunities

Experienced improvements in parenting skills and confidence; improved student behaviour.

Progress towards goal; increase in self-awareness and confidence; taking more responsibility in family life; no improvement in addiction problems.

Increased understanding between community and staff of health service; increased community action; no improvements of child growth.

No changes in school attendance (2003: $55.9 \%$; 2005: $51.3 \%$ ), or youth apprehension (2003: 68; 2005: 75); decline in cannabis use (2001: $80 \%$; 2004: $74 \%, p=.003)$, statistically significant for females (13-36 years, $p=.008)$ and older males $(>16$ years, $p=.007)$.

Increase in visits to health professionals; improved adherence to diabetes management protocol; $65 \%$ decrease in sugar purchases; increase in fruit (81\%) and vegetable (11\%) purchases; no change in biochemical control.

Non-significant increase in school attendance (48.4 to $53 \% ; p>.1$ ); improvements in family environment; no improvements in parental involvement in education; children show more respect towards teachers and other children.

Increase in utilization of the service (1994: 73 people; 1997: 770 people using service).

Increased knowledge, confidence and understanding of financial and money management; increase in employment and re-engagement with education.

New healthy settlement was creating; satisfaction of tenants with new buildings; dissatisfaction with level of involvement

Reduced injury and suicide rate in community; increase in self-esteem and confidence: increase in seeking help instead of going to drugs.

Reduction Indigenous students in lowest literacy bands (2005: $16 \%$; 2006: $6 \%$ ); increase in TAFE enrolments (2001: 1480; 2006: 1718); $32 \%$ increase year 11 and 12 completions; $71 \%$ increase of students finishing certificates and $50 \%$ increase in diplomas; $45 \%$ drop alcohol related hospitalisations, $13 \%$ drop in diabetes-related hospitalisations; decrease in thefts (21.6\%) and breaks (15.8\%) from dwellings.

Significant reduction in frequency of injuries before (96; SE = 4.8) and after (65; SE = 3.08) start of the project (Student's $t=5.07$, $\mathrm{df}=21, p<0.001)$. 
reviewed studies reported positive outcomes for the communities, they are not methodologically rigorous enough to support clear conclusions about their costeffectiveness, and no studies have undertaken an economic analysis to weigh the benefits of community development against its costs. This finding is highly consistent with the conclusions of similar reviews of international Indigenous community development studies, where generally positive outcomes are difficult to interpret because of the relatively poor quality of their evaluation designs and reporting $[9,19,88]$. Published results of community-based evaluations with greater methodological quality are required to provide evidence of cost-effective community development projects [9, 74]. Ideally, future studies would use rigorous evaluation designs, reliable, valid and culturally appropriate measures, economic analysis and a complex intervention framework to balance standardisation and tailoring.

\section{Strengths and limitations}

To ensure that qualitative and quantitative study components were assessed against appropriate criteria the Dictionary for Effective Public Health Practice Project Quality Assessment tool [38] was used to assess the methodological quality of quantitative components and an adaptation of the qualitative study appraisal tool, developed by Long and Godfrey [37] was used for the qualitative study components. The methodological quality of the studies and extent of community participation may have been misclassified, however the high level of agreement between blinded coders suggest not. Of the 231 full-text articles sought for detailed review, 40 (17\%) were excluded because the full text version of these papers were unable to be accessed. Excluding these 40 papers is unlikely to have compromised the comprehensiveness of this review for three reasons: 1) they only represent $17 \%$ of the full-text articles; 2) the majority were older studies or reports that were not publically available; and 3) the references lists of identified publications were hand searched and researchers in the field were consulted to identify publications not found by the electronic database search.

\section{Conclusion}

This systematic review identified that levels of community participation fluctuate across community development project phases: moderate in the Diagnosis and Development phases, high in the Implementation phase, but low in the Evaluation phase. It also identified that the methodological quality of studies evaluating Australian Indigenous community development projects is too weak to confidently determine the cost-effectiveness of these projects in improving the health and wellbeing of Indigenous Australians. Studies of greater methodological quality are required to accurately assess the impact of community development projects. Partnerships combining researchers' expertise and community members' skills and knowledge have great potential to improve methodological quality and community participation in Indigenous community development projects $[9,11,89]$.

\section{Competing interests}

None reported.

\section{Authors' contributions}

MS conducted the literature review and drafted the paper. AS, AW and BC supervised MS in conducting the review and reviewed drafts of the paper. AW assisted in the assessment of the level of community participation. ASt assisted in the appraisal of the quality of methodologies used and the level of community participation, helped design the literature review, consulted on the initial searches and revised drafts of the paper. All authors gave approval for the paper to be published.

\section{Acknowledgements}

The authors gratefully acknowledge the NDARC Education Trustees for funding the PhD candidature of MS. We thank New South Wales Health for funding the Maldahnalanga project, of which this review is a part. We also gratefully acknowledge the Post-Doctoral Research funding from the Northern Research Futures Collaborative Research Network of ASt. We also gratefully acknowledge the input from the Aboriginal community-based partners who are part of the Maldahnalanga project.

\section{Author details}

${ }^{1}$ National Drug and Alcohol Research Centre (NDARC), UNSW, Randwick, NSW 2052 Sydney, Australia. ${ }^{2}$ Public Health and Society, Department of Social Sciences, Wageningen University and Research Centre (WUR), Wageningen, The Netherlands. ${ }^{3}$ The Northern Research Futures Collaborative Research Network, The Cairns Institute, James Cook University (JCU), Cairns, Australia. ${ }^{4}$ National Centre for Epidemiology and Population Health, Research School of Population Health, College of Medicine, Biology and Environment, Australian National University, Canberra, Australia.

Received: 28 April 2015 Accepted: 17 November 2015

Published online: 21 November 2015

\section{References}

1. Vos T, Barker B, Begg S, Stanley L, Lopez A. Burden of disease and injury in Aboriginal and Torres Strait Islander Peoples: the Indigenous health gap. Int J Epidemiol. 2009;38(2):470-7.

2. Steering Committee for the Review of Government Service Provision Overcoming indigenous disadvantage. Key indicators. Melbourne: Commonwealth of Australia; 2011.

3. ABS (Australian Bureau of Statistics). The health and welfare of Australia's Aboriginal and Torres Strait Islander peoples, 2010, in cat. no. 4704.0. Canberra: ABS; 2010.

4. Calabria B, Clifford A, Shakeshaft AP, Doran CM. A systematic review of family-based interventions targeting alcohol misuse and their potential to reduce alcohol-related harm in indigenous communities. I Stud Alcohol Drugs. 2012;73(3):477-88.

5. Clifford A, Pulver L, Richmond R, Shakeshaft A, Ivers R. Smoking, nutrition, alcohol and physical activity interventions targeting Indigenous australians: Rigorous evaluations and new directions needed. Aust N Z J Public Health. 2011;35(1):38-46.

6. Power J, Grealy C, Rintoul D. Tobacco interventions for Indigenous Australians: a review of current evidence. Health Promot J Austr. 2009;20(3):186-94.

7. McCalman J, Tsey K, Clifford A, Earles W, Shakeshaft A, Brainbridge R. Applying what works: a systematic search of the transfer and implementation of promising Indigenous Australian health services and programs. BMC Public Health. 2012;12:600-7.

8. Paul C, Sanson-Fisher R, Stewart J, Anderson A. Being sorry is Not enough. The sorry state of the evidence base for improving the health of indigenous populations. Am J Prev Med. 2010;38:556-8. 
9. Campbell D, Pyett P, McCarthy L. Community development interventions to improve aboriginal health: building an evidence base. Health Sociol Rev. 2007;16(3-4):304-14

10. Clifford A, Doran C, Tsey K. A systematic review of suicide prevention interventions targeting indigenous peoples in Australia, United States, Canada and New Zealand. BMC Public Health. 2013;13(1):463.

11. Mikhailovich K, Morrison P, Arabena K. Evaluating Australian Indigenous community health promotion initiatives: a selective review. Rural Remote Health. 2007;7(2):746

12. Morris PS. Randomised controlled trials addressing Australian Aboriginal health needs: A systematic review of the literature. J Paediatr Child Health. 1999;35(2):130-5.

13. National Health \& Medical Research Council. Values and ethics: guidelines for ethical conduct in Aboriginal and Torres Strait Islander health research.

14. Jamieson LM, Paradies YC, Eades S, Chong A, Maple-Brown L, Morris P, et al. Ten principles relevant to health research among Indigenous Australian populations. Med J Aust. 2012;197(1):16

15. Aboriginal Health and Medical Research Council Ethics Committee. AH\&MRC Guidelines for Research into Aboriginal Health: Key principles. Sydney: Aboriginal Health and Medical Research Council of New South Wales; 2013.

16. WHO. Preamble to the Constitution of the World Health Organization, in International Health Conference. 1948: New York: World Health Organisation.

17. WHO. Ottawa Charter for Health Promotion. in First International Conference on Health Promotion. 1986. Ottawa: World Health Organisation.

18. World Health Organization. Evaluation in Health Promotion: Principles and Perspectives. WHO Regional Publications European Series, vol. 92. Denmark: World Health Organisation; 2001

19. O'Mara-Eves A, Brunton G, McDaid S, Oliver S, Kavanagh J, Jamal F, et al. The effectiveness of community engagement in public health interventions for disadvantaged groups: a meta-analysis. BMC Public Health. 2015;15(1): 129.

20. Haswell-Elkins M, Lyndon R, Fagan R, Ypinazar V, Hunter E, Tsey K, et al. Listening, sharing understanding and facilitating consumer, family and community empowerment through a priority driven partnership in Far North Queensland. Australas Psychiatry. 2009;17 Suppl 1:S54-8.

21. Hunt J, Smith D, Garling S, Sanders W. Contested governance: culture, power and institutions in Indigenous Australia. in CAEPR research monograph. Canberra: ANU E Press; 2008.

22. Schnarch B. Ownership, control, access, and possession (OCAP) or selfdetermination applied to research. J Aborig Health. 2004;1 (1):80-95.

23. Hunt J. Engagement with Indigenous Australia - exploring conditions for effective relationships with Aboriginal and Torres Strait Islander communities. In: Clearinghouse CTG, editor. Issues paper. Canberra: Australian Institute for Health and Welfare; Australian Institute for Family Studies; 2013.

24. Burchill M, Higgins D, Ramsamy L, Taylor S. Workin' together': Indigenous perspectives on community development/Marlene Burchill, Daryl Higgins, et. al., D.J. Higgins, Editor. 2006.

25. Sherwood J. What is community development/by Jaunita Sherwood. 1999

26. Lea DAM, Wolfe JS. Community development planning and Aboriginal community control. Casuarina: Australian National University, North Australia Research Unit; 1993.

27. Liberati A, Altman DG, Tetzlaff J, Mulrow C, Gøtzsche PC, loannidis JPA, et al. The PRISMA statement for reporting systematic reviews and meta-analyses of studies that evaluate health care interventions: explanation and elaboration. PLoS Med. 2009;6(7):e1000100.

28. Thomson Reuter, EndNote. 2014.

29. Ife J. Community Development: community-based alternatives in an age of globalisation. French Forest NSW: Pearson Education Australia Pty Limited; 2002.

30. Hunt J. Strengthening indigenous community governance for sustainability: Using indigenous principles in a community development approach, in community development and ecology: Engaging ecological sustainability through community development. Melbourne: Deakin University; 2008.

31. Sanson-Fisher RW, Campbell EM, Perkins JJ, Blunde, SV, Davis BB. Indigenous health research: A critical review of outputs over time. Med J Aust. 2006;184(8):502.

32. Wagemakers A, Corstjens R, Koelen M, Vaandrager $L$, van't Riet $H$, Dijkshoorn $H$. Participatory approaches to promote healthy lifestyles among Turkish and Moroccan women in Amsterdam. Promot Educ. 2008;15(4):17-23.

33. Wagemakers A, van Husen G, Barrett JB, Koelen MA. Amsterdam's STI/HIV programme: An innovative strategy to achieve and enhance the participation of migrant community-based organisations. Health Education Journal. 2014; 74(4): p. 0017896914542665.

34. Pretty JN. Participatory learning for sustrainable agriculture. World Dev. 1995;23(8):1247-63.

35. Butterfoss FD. Process evaluation for community participation. Annu Rev Public Health. 2006;27:323-40.

36. Nitsch M, Waldherr K, Denk E, Griebler U, Marent B, and Forster R. Participation by different stakeholders in participatory evaluation of health promotion: A literature review. Eval Program Plann. 2013;40:42-54.

37. Long AF, Godfrey M. An evaluation tool to assess the quality of qualitative research studies. Int J Soc Res Methodol. 2004;7(2):181-96.

38. Effective Public Health Practice Project. Quality Assessment Tool for Quantitative Studies Dictionary. 2009. Available from: http://www.ephpp.ca/ PDF/QADictionary_dec2009.pdf. accessed: 21/11/2015.

39. Tsey K, Wenitong M, McCalman J, Whiteside M, Baird L, Patterson D, et al. A participatory action research process with a rural Indigenous men's group: monitoring and reinforcing change. Aust J Prim Health. 2004;10(3):130-6.

40. Gauld S, Smith S, Kendall MB. Using participatory action research in community-based rehabilitation for people with acquired brain injury: from service provision to partnership with Aboriginal communities. Disabil Rehabil. 2011:33(19-20):1901-11.

41. Murphy $L$, Kordyl P, Thorne M. Appreciative inquiry: a method for measuring the impact of a project on the well-being of an Indigenous community. Health Promot J Austr. 2004;15(3):211-4.

42. Lee KS, Conigrave KM, Clough AR, Wallace C, Silins E, Rawles J. Evaluation of a community-driven preventive youth initative in Arnhem Land, Northern Territory. Australia Drug and Alcohol Review. 2008;27(1):75-82.

43. Tyrrell M, Grundy J, Lynch P, Wakerman J. Laramba Diabetes Project: an evaluation of a participatory project in a remote Northern Territory community. 2003. p. 48-53.

44. Salisbury C. A health service and community partnership utilising action research for the development of Aboriginal and Torres Strait Islander services. 1997.

45. Moran MF. An evaluation of participatory planning at Mapoon aboriginal community: Opportunities for inclusive local governance. Aust Aborig Stud. 2003;2:72-84.

46. Jarvie W. Working differently to make a difference to Indigenous communities. Public Administration Today. 2008;14:5-13.

47. Shannon C, Canuto C, Young E, Craig D, Schluter P, Kenny G, et al. Injury prevention in indigenous communities: results of a two-year community development project. Health Promot J Austr. 2001;12(3):233-7.

48. Parker E, Meiklejohn B, Patterson C, Edwards K, Preece C, Shuter P, et al. Our games our health: a cultural asset for promoting health in Indigenous communities. Health Promot J Austr. 2006;17(2):103-8.

49. McMurray L. The Women's Development Project: Indigenous Australia Program: evaluation report. 2012: p. 109.

50. Hunt J. Casestudy 1: The partners - Oxfam Australia and Yorgum Aboriginal Operation. In: Hunt J, editor. Partnerships for indigenous development: Internation development NGOs, aboriginal organisations and communities. Canberra: Centre for Aboriginal Economic Policy Research; 2010.

51. Central Land Council. The warlpiri education and training trust (WETT). In: Kelly L, editor. 2011 report on the central land council community development program. Alice Springs: Central Land Council; 2012.

52. Higgins D. Jarjum youth group. In: Higgins D, editor. Early learnings Telstra foundation research report volume 2: Indigenous community development projects and early learnings. Melbourne: Telstra Foundation; 2005.

53. Smith D. Community action to promote child growth in Gapuwiyak: final report on a participatory action research project/Danielle Smith. Casuarina: Cooperative Research Centre for Aboriginal Health; 2004.

54. McCalman J, Tsey K, Wenitong M, Patterson D, Baird B, Warta D, et al. "No more bandaid solution": Yaba bimbie indigenous Men's support group evaluation report: January 2004-june 2005. Cairns: James Cook University; 2005.

55. Bromfield L, Burchill M. Soaring: Kurruru indigenous youth performing arts. In: Higgins D, editor. Early learnings Telstra foundation research report volume 2: Indigenous community development projects and early learnings. Melbourne: Telstra Foundation; 2005

56. Taylor S. Torres strait paediatric asthma education. In: Higgins D, editor. Early learnings Telstra foundation research report volume 2: Indigenous community development projects and early learnings. Melbourne: Telstra Foundation; 2005

57. Ramsay L. Keeping kids health makes a better world. In: Higgins D, editor. Early learnings Telstra fondation rsearch report volume 2: Indigenous 
community development projects and early learnings. Melbourne: Telstra Foundation; 2005.

58. Guenther J. Evaluation of FAST Galiwin'ku program. Ulverstone: Cat Conatus; 2011.

59. Hunt J. Casestudy 2: ThePartners - caritas Australia and centacare WIlcanniaforbes. In: Hunt J, editor. Partnerships for indigenous development: Internation development NGOs, ABoriginal organisations and communities. Canberra: Centre for ABoriginal Economic Policy Research; 2010.

60. Central Land Council. The granites mine affected areas aboriginal corporation project (GMAAAC). In: Kelly L, editor. Report on the central land council community development program. Alice Springs: Central Land Council; 2012.

61. Central Land Council. The Tanami dialysis project. In: Kelly L, editor. 2011 report on the central land council community development program. Alice Springs: Central Land Council; 2012.

62. Central Land Council. The Uluru-Kata Tjuta Rent Money Project (URM). In: Kelly L, editor. 2011 report on the central land council community development program. Alice Springs: Central Land Council; 2012.

63. Central Land Council. Northern territory parks rent money project. In: Kelly L, editor. 2011 report on the central land council community development program. Alice Springs: Central Land Council; 2012.

64. Taylor S. Traditional indigenous games. In: Higgins D, editor. Early learnings Telstra foundation research report volume 2: Indigenous community development projects and early learnings. Melbourne: Telstra Foundation; 2005.

65. Burchill M, Bromfield L, Higgins D. Ara Irititja Archival Project: knowing the past to strengthen our future. In: Higgins D, editor. Early learnings Telstra foundation research report volume 2: Indigenous community development projects and early learnings. Melbourne: Telstra Foundation; 2005.

66. Ramsay L. Cape york youth network. In: Higgins D, editor. Early learnings Telstra foundation research report volume 2: Indigenous community development projects and early learnings. Melbourne: Telstra Foundation; 2005.

67. Green MJ, Sonn C. In: Sonn CC, editor. Drawing out community empowerment through arts and cultural practice: final report. Perth: Community Arts Network WA; 2009.

68. Ramsay L. Children's picture dictionairies. In: Higgins D, editor. Early learnings Telstra foundation research report volume 2: Indigenous community development projects and early learnings. Melbourne: Telstra Foundation; 2005

69. Tsey K, Deemal A, Whiteside M, Gibson T. "It's an eye-opener for people to see you can change things": an evaluation of a 'family wellbeing' personal and community development pilot project in two Cape York communities. 2003.

70. Wang C, Burris MA. Photovoice: Concept, methodology, and use for participatory needs assessment. Health Educ Behav. 1997;24(3):369-87.

71. Israel BA, Schultz AJ, Parker EA, Becker AA, Allen AJ, Guzman JR. Critical issues in developing and following CPBR Principles, in Community-Based Participatory Research for Health 2nd edition, M. Minkler and N. Wallerstein, Editors., Jossey-Bass: San Fransisco: 2008.

72. Esler DM. Participatory action research in indigenous health. Aust Fam Physician. 2008;37(6):457-9.

73. Whyte WF. Participatory action research. Thousand Oaks: Sage; 1991.

74. Craig P, Dieppe P, Macintyre S, Michie S, Nazareth I, Petticrew M. Developing and evaluating complex interventions: The new medical research council guidance. BMJ. 2008;337:a1665.

75. Bonell CP, Hargreaves J, Cousens S, Ross D, Hayes R, Petticrew M, et al. Alternatives to randomisation in the evaluation of public health interventions: design challenges and solutions. J Epidemiol Community Health. 2011;65(7):582-7.

76. Bowling A, Ebrahim S. Handbook of research methods in health: Investigation, measurement and analysis. Milton Keynes: Open University Press; 2005.

77. Lock M. Aboriginal holistic health: A critical review, in cooperative research centre for aboriginal health discussion paper series. Casuarina: Cooperative Research Centre for Aboriginal Health; 2007.

78. Deady M. A review of screening, assessment and outcome measures for drug and alcohol settings. Sydney: Network of Alcohol and other Drug Agencies (NADA); 2009.

79. Calabria BCA, Shakeshaft A, Conigrave KM, Simpson L, Bliss D, Allan J. Identifying Aboriginal-specific AUDIT-C and AUDIT-3 cut off scores for at risk, high risk and likely dependent drinkers using measures of agreement with the 10-item AUDIT. Addict Sci Clin Pract. 2014:9:17.
80. Stephens A, Graham D, Clough AR. Screening and assessment instruments for use in Indigenous-specific alcohol and drug treatment rehabilitation. Journal of Tropical Psychology. 2013;3:e2.

81. Haswell MR, Kavanagh D, Tsey K, Reilly L, Cadet-James Y, Laliberte A, et al. Psychometric validation of the Growth and Empowerment Measure (GEM) applied with Indigenous Australians. Aust N Z J Psychiatry. 2010;44(9):791-9.

82. Schlesinger CM, Ober C, McCarthy MM, Watson JD, Seinen A. The development and validation of the Indigenous Risk Impact Screen (IRIS): A 13-item screening instrument for alcohol and drug and mental health risk. Drug Alcohol Rev. 2007;26:109-17.

83. Thomas A, Cairney S, Gunthorpe W, Paradies Y, Sayers S. Strong Souls: development and validation of a culturally appropriate tool for assessment of social and emotional well-being in Indigenous youth. Aust N Z J Psychiatry. 2010;44(1):40-8.

84. Campbell M, Fitzpatrick $R$, Haines A, Kinmonth AL, Sandercock $P$, Spiegelhalter D, et al. Framework for design and evaluation of complex interventions to improve health. 321. 2000. 694-696.

85. Davies H, Nutley SM. Healthcare: Evidence to the fore. In: Daves H, Nutley SM, Smith PC, editors. What works? Bristol: Policy Press; 2004.

86. Tong A, Sainsbury P, Craig J. Consolidated criteria for reporting qualitative research (COREQ): a 32-item checklist for interviews and focus groups. Int Qual Health Care. 2007;19(6):349-57.

87. The EQUATOR network. Enhancing the QUAlity and Transparency Of Health Research. 2015 [cited 201523 October]; Available from: http://www.equatornetwork.org/. accessed 21/11/2015.

88. Milton B, Attree P, French B, Povall S, Whitehead M, Popay J. The impact of community engagement on health and social outcomes: a systematic review. Community Development Journal. 2012;47(3):316-34.

89. Roussos ST, Fawcett SB. A review of collaborative partnerships as a strategy for improving communit health. Annu Rev Public Health. 2000;21:369-402.

\section{Submit your next manuscript to BioMed Central and we will help you at every step:}

- We accept pre-submission inquiries

- Our selector tool helps you to find the most relevant journal

- We provide round the clock customer support

- Convenient online submission

- Thorough peer review

- Inclusion in PubMed and all major indexing services

- Maximum visibility for your research 